\title{
Transepithelial Water Flow Regulates Apical Membrane Retrieval in Antidiuretic Hormone-stimulated Toad Urinary Bladder
}

\author{
H. William Harris, Jr., „§ James B. Wade,‡ and Joseph S. Handler* \\ *Laboratory of Kidney and Electrolyte Metabolism, National Heart, Lung and Blood Institute, National Institutes of Health, \\ Bethesda, Maryland 20892; †Department of Physiology, University of Maryland School of Medicine, Baltimore, Maryland 21201; \\ §Division of Nephrology, The Children's Hospital, Boston, Massachusetts 02115
}

\begin{abstract}
Antidiuretic hormone (ADH) increases the osmotic water permeability $\left(\boldsymbol{P}_{\text {oem }}\right)$ of toad urinary bladder. This increase is believed to be produced by fusion of intracellular vesicles called aggrephores with the granular cell apical plasma membrane. Aggrephores contain intramembrane particle aggregates postulated to be water channels. ADH-stimulated $\boldsymbol{P}_{\text {oem }}$ is decreased by osmotic gradient exposure, which is termed flux inhibition. We studied flux inhibition by exposing ADH-stimulated bladders to various osmotic gradients. Osmotic water flow was initially proportional to the applied osmotic gradient, but $\boldsymbol{P}_{\text {oem }}$ decreased with time. Ultrastructural and quantitative studies of endocytosis demonstrate that apical membrane retrieval was a direct function of the transepithelial osmotic gradient. $P_{\text {osm }}$ remained unchanged when apical membrane retrieval was blocked by incubation of bladders at $2^{\circ} \mathrm{C}$, or under low water-flow conditions. These effects were reversed by increases in temperature or the applied osmotic gradient. We conclude that apical membrane retrieval causes the phenomenon of flux inhibition.
\end{abstract}

\section{Introduction}

The toad urinary bladder has been studied extensively in order to understand the mechanism of action of antidiuretic hormone $(\mathrm{ADH})^{1}$ in so-called "tight epithelia." The binding of $\mathrm{ADH}$ to receptors on the basolateral surface of this epithelium produces a large increase in water permeability of the granular cell apical membrane as well as increases in urea permeability and active sodium transport (1). ADH increases the granular cell content of cyclic AMP (2) which, through a series of unknown steps, causes the fusion of unique tubular-shaped cytoplasmic vesicles (termed aggrephores) with the apical plasma membrane (3-5). Distinctive intramembrane particle aggregates visualized by freeze-fracture electron microscopy $(6,7)$, are contained within the aggrephore-limiting membrane. Upon stimulation with $\mathrm{ADH}$, aggrephores fuse with the granular cell apical plasma membrane and deliver the aggregates into the bilayer of the apical membrane. A large body of evidence indicates that particle aggregates are closely correlated with or are themselves water

Address reprint requests to Dr. Harris, Building 10, Room 6N307, National Institutes of Health, Bethesda, MD 20892.

Received for publication 18 February 1986.

1. Abbreviations used in this paper: $\mathrm{ADH}$, antidiuretic hormone; F-dextran, fluorescein-conjugated dextran; HRP, horseradish peroxidase; R-HRP, rhodamine-labeled horseradish peroxidase.

The Journal of Clinical Investigation, Inc.

Volume 78, September 1986, 703-712 channels responsible for the increase in apical membrane water permeability induced by ADH (reviews 8, 9). Freeze-fracture electron microscopy has also revealed that distinctive intramembrane particle structures are closely correlated with ADHinduced permeability changes in the apical membrane of the mammalian collecting duct (10-12).

In the presence of an osmotic gradient (mucosal bath hypotonic with respect to the serosal bath), the addition of $\mathrm{ADH}$ to toad urinary bladder causes a prompt increase in osmotic water flow, which diminishes within minutes despite the continued presence of hormone and osmotic driving force (13-15). Hays and Leaf (16) measured ADH-stimulated water flow across toad bladder during the initial 30-45-min interval after hormone stimulation. They found it to be a linear function of the transepithelial osmotic gradient. Subsequently, Eggena (17) observed that a brief glutaraldehyde fixation of the mucosal surface preserved the bladder's water permeability characteristics for subsequent analysis. Using this technique, he demonstrated that $\mathrm{ADH}$ stimulation in the presence of an osmotic gradient caused a decrease in apparent water permeability when compared with a paired tissue stimulated under isosmotic conditions $(18,19)$. This phenomenon, which he termed "flux inhibition," has been independently confirmed by others (20-23). Similarly, Parisi et al. (24) noted that, when frog urinary bladders were stimulated with ADH under isosmotic conditions and then exposed to an osmotic gradient, water flow was initially very large but rapidly attenuated. The foregoing differences in water permeability have been correlated with differences in the numbers of aggregates and aggrephore fusion events in the apical membrane. There is an increased number of particle aggregates and aggrephore fusion events in toad bladders stimulated with $\mathrm{ADH}$ in the absence as compared with the presence of a 175 mosM transepithelial osmotic gradient despite exposure to an identical concentration of $\mathrm{ADH}(20-23)$. These observations suggest that, independent of hormone concentration, granular cells alter their water permeability through events occurring at the granular cell apical plasma membrane.

Recent studies have shown that the presence of an osmotic gradient markedly increases granular cell uptake of enzymatic $(25,26)$ and fluorescent $(27)$ tracers during ADH stimulation and $\mathrm{ADH}$ removal. The tracers are found largely in tubular vesicles and multivesicular bodies (25). However, other reports (4, 21) disagree as to the importance of apical membrane retrieval during continuous $\mathrm{ADH}$ stimulation in the presence of an osmotic gradient.

This study was designed to evaluate the role of apical membrane retrieval in the "flux inhibition" of ADH-stimulated toad bladder. We show that the osmotic water permeability $\left(P_{\text {osm }}\right)$ of ADH-stimulated bladders is reduced in inverse proportion to transepithelial water flow. The data are correlated with ultrastructural and fluorescence measurements, which show that at 
$23^{\circ} \mathrm{C}$ apical membrane retrieval is a function of transepithelial water flow above a threshold water flow rate of $2 \mu \mathrm{l} / \mathrm{min} / \mathrm{cm}^{2}$. Maneuvers that block apical membrane retrieval in ADH-stimulated bladders (incubation at $2^{\circ} \mathrm{C}$ or subthreshold values of osmotic water flow) block the fall in $P_{\text {osm }}$ and result in the maintenance of epithelial water permeability. When water flow is subsequently increased (increase in temperature or applied osmotic gradient), membrane retrieval is stimulated and water permeability falls rapidly. The above evidence indicates that apical membrane retrieval is responsible for the phenomenon of flux inhibition.

\section{Methods}

Hemibladders from Bufo marinus (National Reagents) were prepared as previously described (28). Hemibladders were initially filled to maximal distension with and suspended in an amphibian Ringer's solution of the following composition: $110 \mathrm{mM}$ sodium chloride, $2.5 \mathrm{mM}$ sodium bicarbonate, $3 \mathrm{mM}$ potassium chloride, $2 \mathrm{mM}$ potassium dihydrogen phosphate, $1 \mathrm{mM}$ calcium chloride, $0.5 \mathrm{mM}$ magnesium sulfate, and 5 $\mathrm{mM}$ glucose, $\mathrm{pH} 7.8,215 \mathrm{mosmol} / \mathrm{kg} \mathrm{H}_{2} \mathrm{O}$. The Ringer's solution was equilibrated and stirred by bubbling with room air. After an equilibration period of $\mathbf{3 0} \mathrm{min}$, the mucosal solution was replaced with fresh Ringer's solution or one in which the osmolality was reduced to $40 \mathrm{mosmol} / \mathrm{kg}$ $\mathrm{H}_{2} \mathrm{O}$ by reduction in the concentration of sodium chloride. The bladders were then stimulated by addition of arginine vasopressin (Sigma Chemical Co., St. Louis, MO) to a final concentration of $50 \mathrm{mU} / \mathrm{ml}$ in the serosal bath. This concentration of ADH exceeds that needed to stimulate maximal water flow in the presence of a 175 mosM gradient. When present for $15 \mathrm{~min}$ under isotonic conditions, $50 \mathrm{mU} / \mathrm{ml}$ of ADH causes maximal water permeability (20) and near-maximal numbers of aggrephore fusion events (21). The mucosal solution of bladders stimulated under isosmotic conditions was then rapidly replaced by one of a variety of hypotonic Ringer's solutions each produced by adjustment of sodium chloride concentration. Osmotic water flow was measured gravimetrically (29) by weighing single hemibladders at 1-, 2-, or 5-min intervals. The rate of water flow was expressed as milligrams per minute per square centimeter assuming fully distended hemibladders were spherical. $P_{\text {oem }}$ was calculated as discussed by Kachadorian and Levine (30) and expressed as micrometers per second. Each weighing necessitated removal of a hemibladder from the serosal bath for 10-14 s. Repetitive measurements of bladder weight in the absence of water flow varied by $<0.02 \%(\sim 1 \mathrm{mg})$. In some experiments, hemibladders were rapidly chilled to $2^{\circ} \mathrm{C}$ by replacement of the mucosal and serosal solutions by chilled Ringer's solutions of the appropriate composition followed by incubation in an ice bath. Bladders were rewarmed by replacing the mucosal and serosal solutions with those at $23^{\circ} \mathrm{C}$.

Fluorescent dextran uptake measurements. Measurements of uptake of fluorescent dextran or horseradish peroxidase (HRP) by granular cells were performed as previously described (27) using fluorescein-conjugated dextran (F-dextran) and rhodamine-labeled horseradish peroxidase ( $R$ HRP) at concentrations of 20 and $5 \mathrm{mg} / \mathrm{ml}$, respectively. The fluorescent marker was present in the mucosal solution in contact with the apical surface of granular cells during the uptake period as described in the text. This was followed by removal of the marker, rinsing the mucosal surface with Ringer's solution of the appropriate composition, mounting the bladder on a plastic ring, and observation of the intact unfixed epithelium by epifluorescence microscopy.

HRP uptake measurements. Hemibladders were stimulated with $\mathbf{5 0}$ $\mathrm{mU} / \mathrm{ml}$ of ADH for $15 \mathrm{~min}$ in the absence of a transepithelial osmotic gradient. The mucosal solution of each bladder was then replaced with a single solution containing $10 \mathrm{mg} / \mathrm{ml}$ of HRP (Sigma Chemical Co., Type II), which had been dialyzed against one of a number of Ringer's solutions of various osmotic strength (see above). After a 10-min incubation period, the mucosal solution was removed and the bladders were rapidly chilled to $2^{\circ} \mathrm{C}$ (see above). All subsequent steps were performed at $2^{\circ} \mathrm{C}$. The mucosal surface was rinsed with five exchanges of Ringer's solution, followed by five rinses with distilled water made isotonic ( 215 mosmol $/ \mathrm{kg} \mathrm{H}_{2} \mathrm{O}$ ) with $6.25 \% \mathrm{wt} / \mathrm{vol}$ sucrose. Epithelial cells were removed from the bladders'by scraping with a glass slide. Cells from duplicate bladders were combined to obtain enough material for convenient assay and rinsed in isosmotic sucrose solution by centrifugation at $3,110 \mathrm{~g}$ for $3 \mathrm{~min}$. Peroxidase activity in the cell pellet was measured as described by Steinman and Cohn (31) with and without the addition of Triton X-100 (Bio-Rad Laboratories, Richmond, CA) to a final concentration of $1 \%$. All peroxidase activity was expressed as optical density per minute per microgram of protein. Protein was assayed by the method of Bradford (32).

Electron microscopy. Bladders were exposed to R-HRP at a concentration of $5 \mathrm{mg} / \mathrm{ml}$ on the apical surface for a 10 -min period in the presence or absence of osmotic gradients as described in the text. After incubation with R-HRP, bladders were chilled to $2^{\circ} \mathrm{C}$ and rinsed 10 times with isotonic or hypotonic Ringer's solutions. The bladders were fixed in $2.5 \%$ glutaraldehyde buffered by cacodylate for $20 \mathrm{~min}$ and peroxidase activity was localized by incubation with $3,3^{\prime}$-diaminobenzidine tetrahydrochloride and hydrogen peroxide (33). Tissue samples were coded and localization was evaluated without knowledge of the tissue's treatment.

\section{Results}

Initial water flow is proportional to an osmotic gradient before flux inhibition. Fig. 1 shows the osmotic water flow across bladders that were stimulated with ADH in the absence of an osmotic gradient, followed by imposition of different hypotonic mucosal solutions to produce a series of transepithelial osmotic gradients. In those bladders subjected to large osmotic gradients, the initial

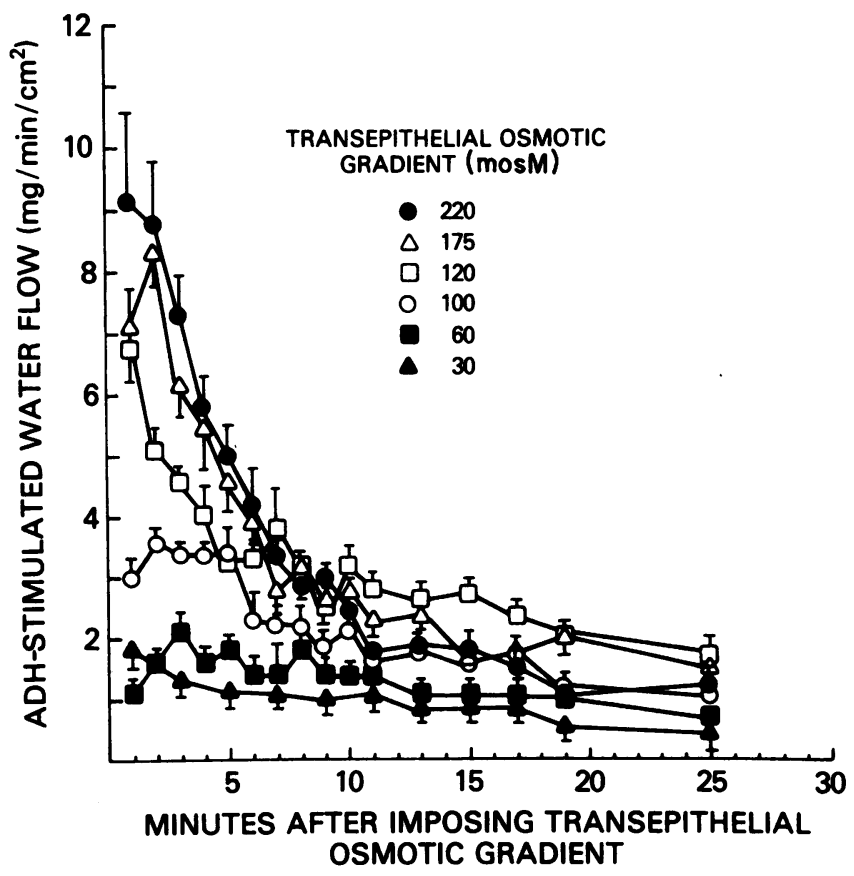

Figure 1. Osmotic water flow in toad bladders stimulated with ADH in the absence of an osmotic gradient followed by institution of a series of transepithelial osmotic gradients. Toad bladder sacs were stimulated with $50 \mathrm{mU} / \mathrm{ml}$ of ADH under isotonic conditions for $15 \mathrm{~min}$. The mucosal solutions were then rapidly replaced with fresh Ringer's solutions of varying osmotic compositions to create a graded series of transepithelial osmotic gradients. Osmotic water flow occurred in a mucosal to serosal direction and was measured gravimetrically. Each value shown represents the mean \pm SEM of six independent experiments. 
high rate of water flow was rapidly attenuated. As anticipated, those bladders exposed to smaller osmotic gradients had a proportionally lower initial rate of $\mathrm{ADH}$-stimulated water flow. These bladders showed little or no decrease in osmotic water flow with time. The substantial decreases in water flow in bladders subjected to large transepithelial osmotic gradients were not due to dissipation of the osmotic driving force. Replacement of the mucosal solution with fresh hypotonic Ringer's solution of initial osmolality at any time during the first 25 min caused no change in flow (data not shown).

The average osmotic water flow during the initial 5-min interval depicted in Fig. 1 was proportional to the transepithelial osmotic gradient (Fig. 2). With increasing time, there is progressive flattening of this curve. Fig. 3 depicts the osmotic water permeability $\left(P_{\text {osm }}\right)$ of these bladders during the initial 5-min period of water flow as well as the interval between 15 and 20 min. During the initial 5-min period, values of $P_{\text {osm }}(O)$ were $>220 \mu \mathrm{m} / \mathrm{s}$ regardless of the osmotic driving force. The initial values of $P_{\text {osm }}$ found here are in reasonable agreement with those previously published $(34,35)$. In contrast, the $P_{\text {osm }}$ values for the $15-20$-min interval ( $(\bullet)$ decreased to $<20 \%$ of their original value with increasing osmotic gradients. Under these conditions, the magnitude of the decrease in water permeability is related to transepithelial osmotic driving force.

Flux inhibition is not due to sweeping-away effects. Several authors $(36,37)$ have called attention to the polarization of solutes caused by sweeping-away effects during water flow across epithelia. Sweeping-away effects lower the osmotic gradient at the flow-limiting membrane and thus lower the apparent osmotic water permeability in a time-dependent fashion. This effect was demonstrated by Wright et al. (38) who showed the symmetric weight gain of a rabbit gallbladder sac when it was bathed with an isotonic solution on both surfaces after weight loss due to water flow along an osmotic gradient. To test if sweeping-away effects could account for the attenuation of water flow observed in $\mathrm{ADH}$-stimulated bladders exposed to an osmotic gradient

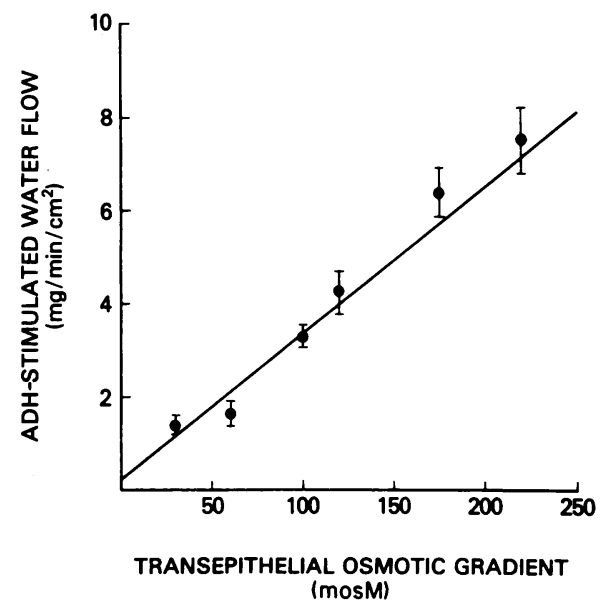

Figure 2. The ADH-stimulated osmotic water flow in toad bladder sacs during the initial 5-min interval after osmotic gradient imposition. Bladders sacs were manipulated as described in Fig. 1. and the mean water flow during the 5-min interval immediately after imposition of an osmotic gradient was expressed as a function of the transepithelial osmotic gradient. Each point and bracket represents the mean \pm SEM of six independent experiments. The $r$ value for the least squares line displayed is $\mathbf{0 . 9 7 2}$.

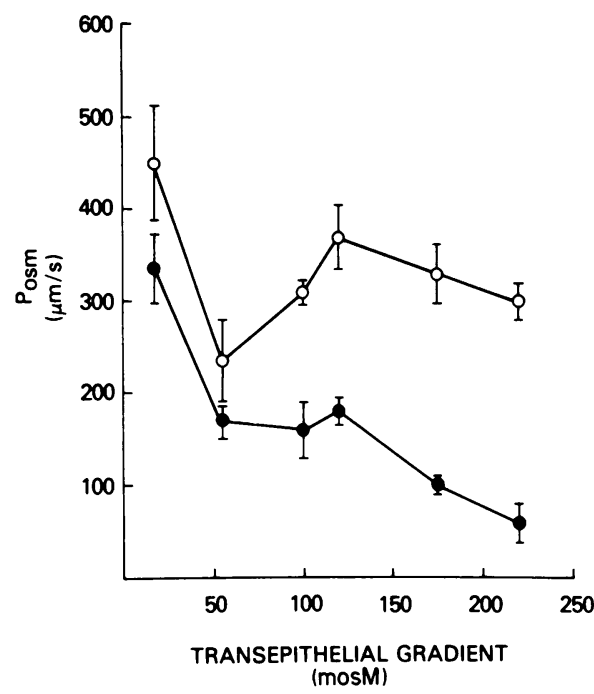

Figure 3. Comparison of the mean osmotic water permeabilities $\left(P_{\mathrm{f}}\right.$ or $\left.P_{\text {osm }}\right)$ of toad bladder sacs during the initial 5- and 15-20-min intervals after institution of an osmotic gradient. Bladders sacs were manipulated as described in Fig. 1 and the mean $P_{\text {osm }}$ values for the initial 5min interval (o) compared with a 5-min interval between 15 and 20 min (•) after imposition of a particular osmotic gradient. The calculated values represent the mean \pm SEM of six independent experiments.

(Fig. 1), we performed two experiments similar to those of Wright et al. (38). Bladders were stimulated with $\mathrm{ADH}$ in the absence of an osmotic gradient, exposed to a 175 mosM gradient for 10 min and then bathed with isotonic solutions on both surfaces. There was no weight gain under these conditions (Fig. 4, left). Other bladders were stimulated with $\mathrm{ADH}$ in the absence of an osmotic gradient, then subjected to intervals of 175 mosM gradient interspersed with periods in which the bladder was cooled to $2^{\circ} \mathrm{C}$ under isotonic conditions (Fig. 4, right). The isotonic incubation in the cold for $15 \mathrm{~min}$ allows the dissipation of regions of polarized solute; the decrease in temperature retards cellular membrane processing that might occur during this interval (see below). Incubating the tissue under isotonic conditions at $2^{\circ} \mathrm{C}$ had no effect on the subsequent ADH-stimulated water flow that occurs when the gradient was restored. Once water flow was attenuated in the presence of an osmotic gradient, a second period of isotonic incubation at $2{ }^{\circ} \mathrm{C}$ did not increase the rate of ADH-stimulated water flow. Thus, sweeping-away effects cannot account for the large decrease in water permeability observed in ADH-stimulated toad bladders under these conditions.

Decrease in water permeability is correlated with granular cell uptake of fluorescent markers. Previous studies have demonstrated that granular cell uptake of fluid phase markers from the mucosal bathing solution during continuous $\mathrm{ADH}$ stimulation is greatly enhanced by an osmotic gradient $(25,26)$. In addition, freeze-fracture electron microscopic studies have shown that the number of particle aggregates and aggrephore fusion events in the granular cell membrane is decreased by a transepithelial osmotic gradient during both $\mathrm{ADH}$ stimulation (20, 21 ) and the period immediately after hormone removal (2123). To determine whether apical membrane retrieval was correlated with decreases in water permeability as shown in Fig. 1, we used fluorescent dextrans (F-dextran) and rhodamine-labeled horseradish peroxidase (R-HRP) to evaluate the effect of osmotic gradients on membrane retrieval. 

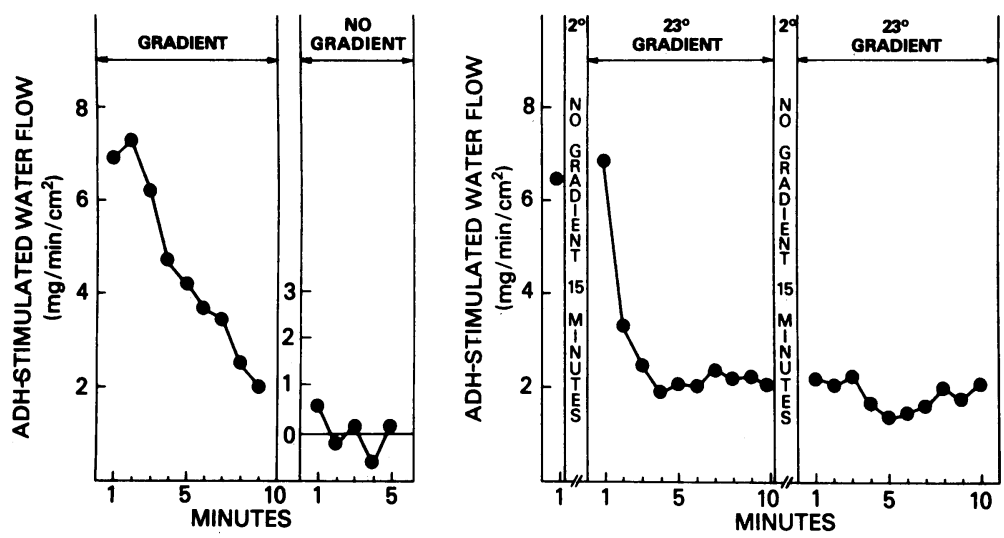

Figure 4. ADH-stimulated osmotic water flow in toad bladders subject to isotonic or low temperature conditions after attenuation of osmotic water flow. As shown on the left, after $15 \mathrm{~min}$ of $\mathrm{ADH}$ stimulation $(50 \mathrm{mU} / \mathrm{ml})$ under isotonic conditions, a sac was subjected to a 175 mosM (mucosal solution hypotonic to serosal solution) osmotic gradient which produced a prompt attenuation of osmotic water flow. Water flow was recorded as the loss of weight by the sac. After $10 \mathrm{~min}$, the mucosal solution was replaced with isotonic Ringer's solution and the sac was monitored for reciprocal weight gain. Alternatively, as shown on the right, a bladder was stimulated with $\mathrm{ADH}$ under isotonic conditions, a 175 mosM gradient was imposed, and a 1-min water flow measurement was obtained at $23^{\circ} \mathrm{C}$. The mucosal and serosal solutions of the sac were then replaced with isotonic Ringer's solution at $2^{\circ} \mathrm{C}$ and the bladder was incu-

bated for $15 \mathrm{~min}$. Upon rewarming to $23^{\circ} \mathrm{C}$ in the presence of a $175 \mathrm{mosM}$ gradient, there was a prompt attenuation of water flow. The bladder was then placed in isotonic conditions at $2^{\circ} \mathrm{C}$ for another $15 \mathrm{~min}$, and then rewarmed to $23^{\circ} \mathrm{C}$ in a 175 mosM gradient and osmotic water flow was measured for an interval of $10 \mathrm{~min}$. These data are representative recordings of individual bladder sacs of an experimental protocol performed nine times.

Bladders were stimulated with ADH in the presence or absence of an osmotic gradient, then the mucosal solution was replaced with a hypotonic or isotonic solution containing Fdextran. After a 10-min incubation in the presence or absence of water flow, the mucosal solution was removed, the mucosal surface rinsed with the appropriate Ringer's solution without F-dextran, and the living bladder was mounted and observed by epifluorescence microscopy. The serosal surface of each bladder was continuously exposed to $50 \mathrm{mU} / \mathrm{ml}$ of ADH throughout these manipulations. Those bladders that were stimulated in the absence of a gradient and then exposed to an osmotic gradient internalized large amounts of F-dextran (Fig. $5 \mathrm{~B}$ ) while bladders exposed to F-dextran under isotonic conditions were found to internalize very little of the label (Fig. $5 \mathrm{~A}$ ). There was also extremely little uptake of label if bladders were initially exposed to ADH in the presence of a gradient but shifted to isotonic conditions during the period of dextran exposure (Fig. $5 \mathrm{C}$ ). Significant F-dextran uptake was observed in bladders exposed to hypotonic F-dextran after initial ADH stimulation in the presence of a gradient (Fig. $5 \mathrm{D}$ ), but this level of uptake was less than in bladders stimulated under isotonic conditions (Fig. $5 \mathrm{~B}$ ). Thus, under these conditions, the internalization of Fdextran that quantifies apical membrane retrieval was completely dependent on water flow.

Fluorescent markers are localized to distinctive tubular vesicles. Identical fluorescence results were obtained using R-HRP. Peroxidase activity was then localized by electron microscopy. Bladders incubated with R-HRP for $10 \mathrm{~min}$ in the absence of an osmotic gradient after a 15-min stimulation with ADH under isotonic conditions showed no significant internalization of the label (data not shown). However, identically treated bladders exposed to a 175 mosM gradient showed a striking intracellular localization of HRP activity near the apical surface (Fig. $6 \mathrm{~A}$ ). In many instances (solid arrows, Fig. $6 \mathrm{~A}$ ), the label occurred in long tubular vesicles of $0.09 \mu \mathrm{m}$ in diameter and $0.3-0.5 \mu \mathrm{m}$ in length. The diameter of other labeled vesicles observed (open arrows, Fig. $6 \mathrm{~A}$ ) indicates that these structures represent various sections of similar long tubular vesicles. Only very rarely (asterisk, Fig. $6 \mathrm{~A}$ ) were labeled vesicles observed that did not conform to this pattern. Bladders initially stimulated with ADH in the presence of an osmotic gradient but transferred to isotonic conditions for the 10-min period of labeling showed very little intracellular uptake of R-HRP (Fig. 6 B). In contrast, if osmotic water flow continued during the period of R-HRP labeling, there was marked labeling of tubular vesicles (Fig. $6 C$ ). The number

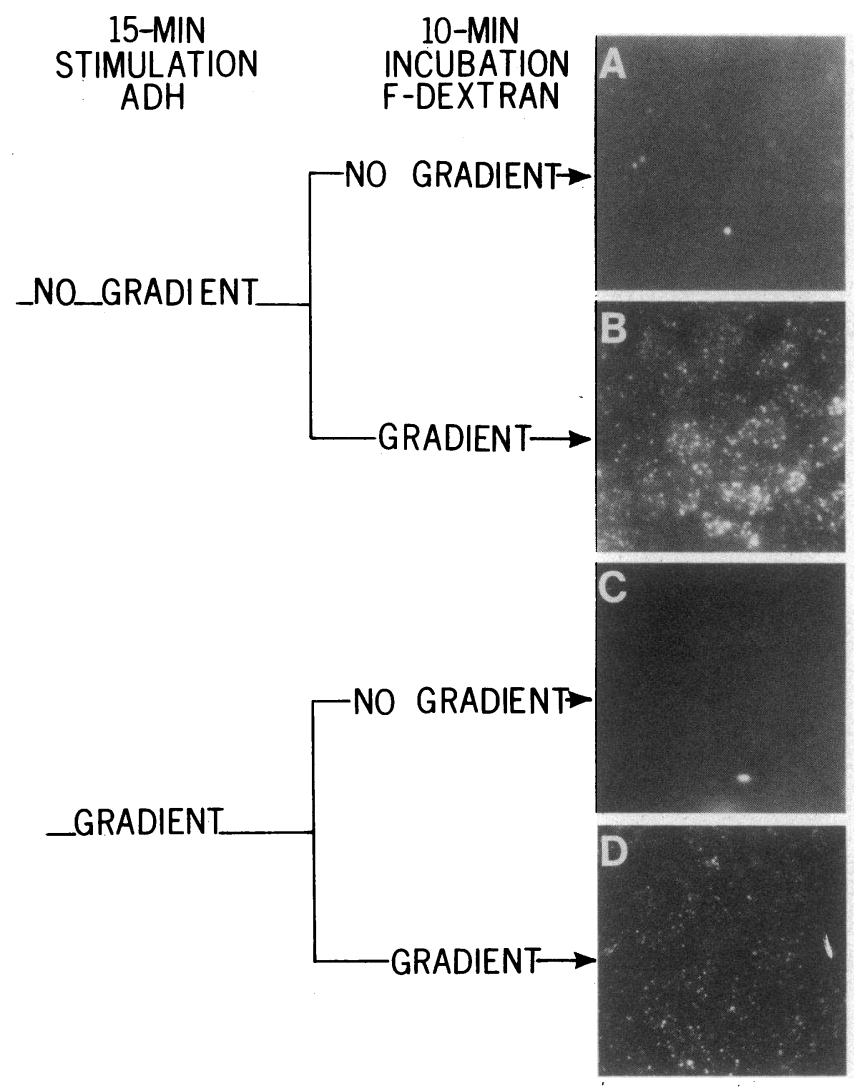

Figure 5. The influence of an osmotic gradient on granular cell uptake of F-dextran. Toad bladder sacs were stimulated for $15 \mathrm{~min}$ with 50 $\mathrm{mU} / \mathrm{ml}$ of ADH in the presence or absence of a 175 mosM gradient. The mucosal solution of a sac was then replaced with either isotonic ( $215 \mathrm{mosmol} / \mathrm{kg} \mathrm{H}_{2} \mathrm{O}$ ) or hypotonic ( $40 \mathrm{mosmol} / \mathrm{kg} \mathrm{H}_{2} \mathrm{O}$ ) solution containing $20 \mathrm{mg} / \mathrm{ml}$ of $\mathrm{F}$-dextran and incubated for $10 \mathrm{~min}$. The $\mathrm{mu}$ cosal solution was aspirated, and the bladder's mucosal surface was rinsed to remove adherent dextran, mounted, and observed by epifluorescence microscopy (see Methods). The final magnification of all photographs is $\times 845$. 


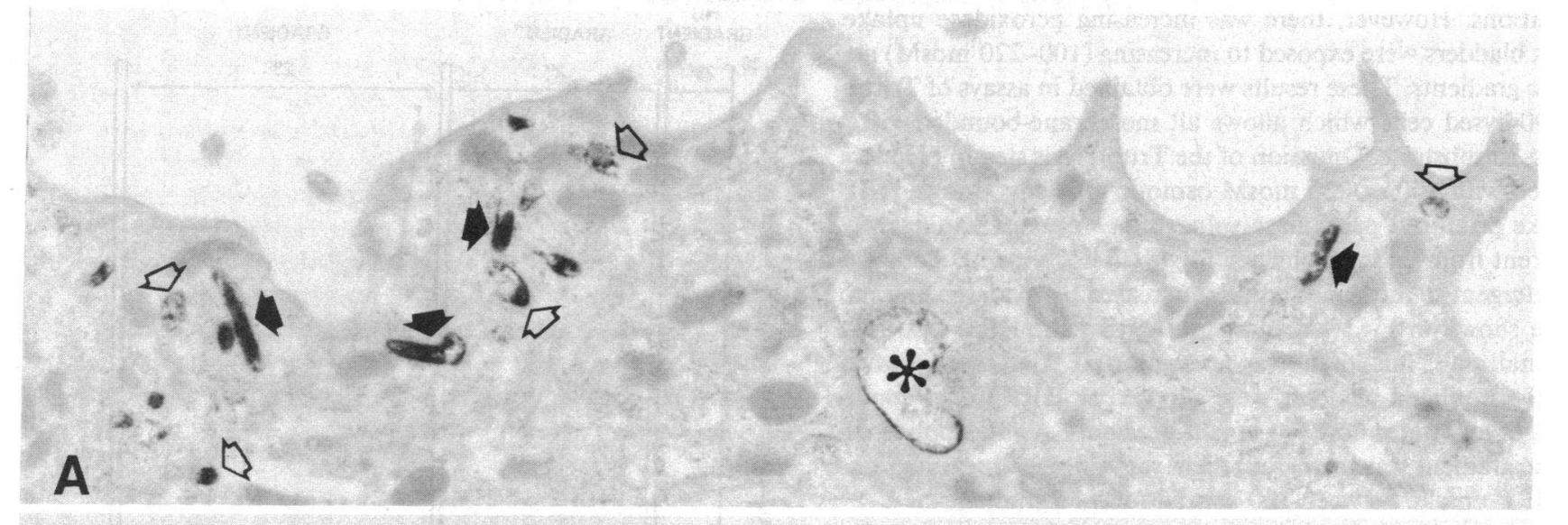

B
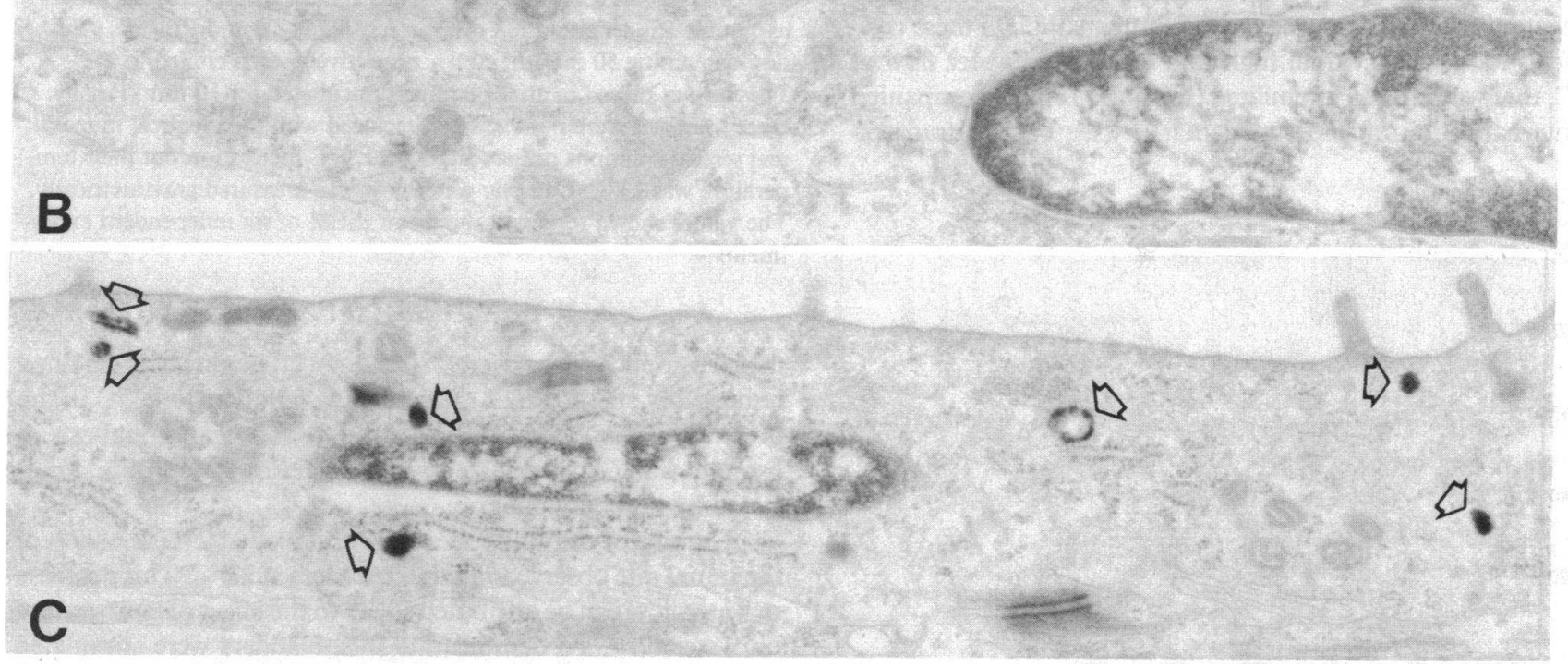

Figure 6. The influence of an osmotic gradient on the uptake of R-HRP: electron microscopic localization. Bladders were exposed to $\mathrm{ADH}$ and 175 mosM osmotic gradients following the protocol of Fig. 5. (A) After exposure to ADH in the absence of an osmotic gradient, the incubation with R-HRP $(5 \mathrm{mg} / \mathrm{ml})$ in the presence of a gradient labels distinctive long tubular vesicles (solid arrows). Other labeled vesicles (open arrows) appear to be sections through such tubules.

of labeled vesicles was greater in bladders stimulated with ADH under isotonic conditions, followed by exposure to an osmotic gradient as compared with bladders continuously exposed to an osmotic gradient during the initial ADH-stimulation and RHRP-labeling periods. HRP labeling in both of the above cases was markedly greater than in bladders exposed to R-HRP label under isotonic conditions. Thus, the ultrastructural labeling closely paralleled the fluorescent pattern described in Fig. 5 and indicates that a 175 mosM osmotic gradient causes a rapid retrieval of apical membrane into distinctive tubular vesicles.

Apical membrane retrieval is proportional to water flow. If retrieval of membrane containing the water channels is respon-
Only rarely are other types of vesicles labeled (asterisk). $\times 23,000$. (B) Bladders exposed to ADH in the presence of a gradient but incubated with R-HRP in the absence of an osmotic gradient show very few labeled vesicles (arrow). $\times 27,500$. $(C)$ Bladders exposed to ADH in the presence of an osmotic gradient as in $B$ but incubated with R-HRP in the presence of an osmotic gradient show more labeled vesicles ( $a r$ rows) than $B$ but fewer than $A$. $\times 23,000$.

sible for the flow-dependent decrease in osmotic water permeability observed in ADH stimulated bladders, then internalization of apical membrane should be proportional to the transepithelial osmotic gradient. Fig. 7 illustrates the results of four independent experiments assaying peroxidase activity in epithelial cells scraped from toad bladders. Prior to scraping, the bladders were stimulated with $\mathrm{ADH}$ under isosmotic conditions, then exposed on the mucosal surface to HRP solutions of different osmotic activity. Scraped control epithelial cells had a significant amount of endogenous peroxidase activity. There was no significant increase above endogenous peroxidase levels in bladders exposed to HRP under isosmotic or 60 mosM gradient 
conditions. However, there was increasing peroxidase uptake when bladders were exposed to increasing (100-220 mosM) osmotic gradients. These results were obtained in assays of Triton X-100-lysed cells which allows all membrane-bounded HRP access to substrate. Omission of the Triton lysis step in bladders treated with 100 or 220 mosM osmotic gradients during HRP uptake produced peroxidase values that were not significantly different from endogenous activity (data not shown). Addition of detergent to the same samples increased peroxidase values to those shown in Fig. 7, demonstrating that the HRP was truly internalized. Thus, there was no significant HRP uptake when ADH-stimulated bladders were exposed to HRP under conditions of low water flow (60 mosM gradient). As the applied osmotic gradient was increased, there was a nearly linear increase in HRP uptake between 100 and 220 mosM gradients.

Low temperature blocks the decrease in water permeability and dextran uptake. Endocytosis of the plasma membrane in many cell types is blocked by a decrease in temperature to below $5^{\circ} \mathrm{C}$ (39). Fig. 8 illustrates the effect on $\mathrm{ADH}$-stimulated water flow of rapidly cooling ADH-stimulated bladders to $2^{\circ} \mathrm{C}$. After ADH stimulation for $15 \mathrm{~min}$ in the absence of a gradient, bladders were exposed to a 175 mosM gradient at $2^{\circ} \mathrm{C}$ for $10 \mathrm{~min}$ and water flow was measured each minute. Although these conditions produced an initial high rate of osmotic water flow at $23^{\circ} \mathrm{C}$, that was rapidly attenuated (see Fig. 1) and accompanied by internalization of fluorescent marker (see Fig. 5); transepi-

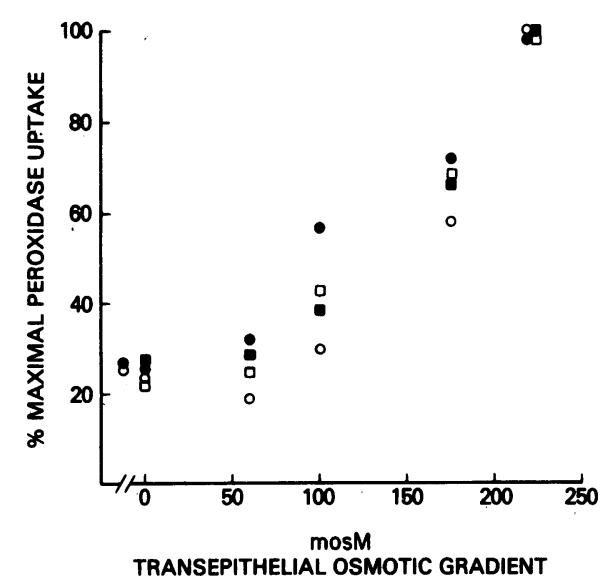

Figure 7. Quantitation of HRP uptake by granular cells as a function of transepithelial osmotic gradient. Toad bladder sacs were stimulated with $50 \mathrm{mU} / \mathrm{ml}$ of $\mathrm{ADH}$ under isotonic conditions for $15 \mathrm{~min}$. The mucosal solution of each bladder was then replaced with a solution of different osmolality containing $10 \mathrm{mg} / \mathrm{ml}$ of HRP and the incubation continued for an additional $10 \mathrm{~min}$. The bladders were then chilled to $20^{\circ} \mathrm{C}$, the mucosal surface was rinsed extensively, and the epithelial cells were scraped with a glass slide. The epithelial cells were processed and assayed for peroxidase activity. The results of four independent experiments are depicted by the symbols $\square, \square, 0$, and $\bullet$, respectively, and expressed as percent peroxidase activity relative to maximal HRP uptake with a 220 mosM gradient. The values immediately to the right of the ordinate represent endogenous peroxidase activity present in bladders not exposed to HRP. The symbols above the values 0-220 on the abscissa depict the peroxidase activity in cells from bladders exposed to solutions of HRP of the indicated osmolality. Note that the peroxidase values of bladders exposed to HRP under isosmotic or 60 mosM gradient conditions are not different from endogenous levels. However, exposure to HRP under 100-220 mosM gradient conditions produces a near-linear increase in peroxidase activity.

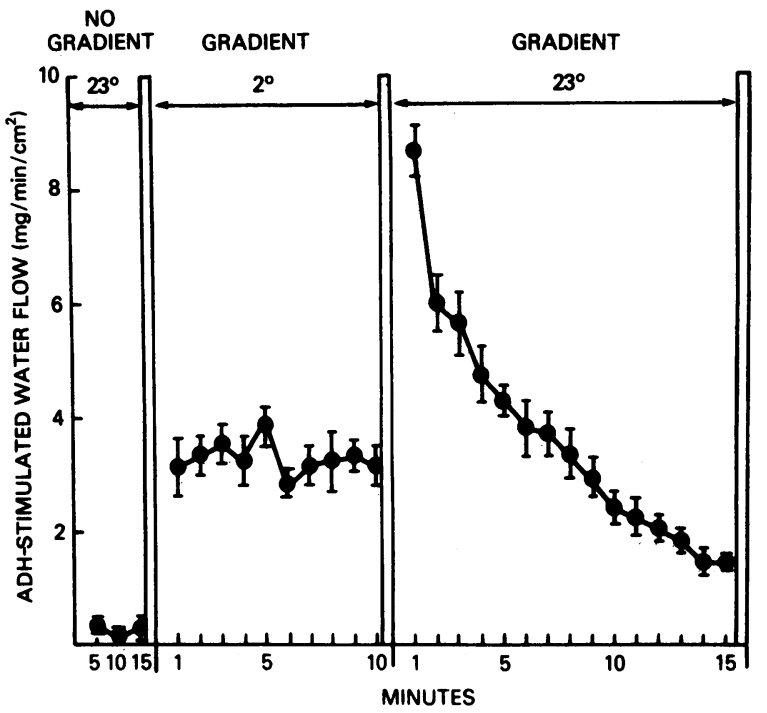

Figure 8. The effect of rapid cooling on ADH-stimulated water flow in toad urinary bladder. Bladder sacs were initially stimulated for $15 \mathrm{~min}$ with $50 \mathrm{mU} / \mathrm{ml}$ of $\mathrm{ADH}$ under isotonic conditions at $23^{\circ} \mathrm{C}$. The mucosal and serosal solutions were rapidly removed and replaced with hypotonic Ringer's solution ( $40 \mathrm{mosmol} / \mathrm{kg} \mathrm{H}_{2} \mathrm{O}$ ) and Ringer's solution containing $50 \mathrm{mU} / \mathrm{ml} \mathrm{ADH}$, respectively, each chilled to $2^{\circ} \mathrm{C}$. The sac was placed in an ice bath and incubated for $10 \mathrm{~min}$. Finally, these solutions were removed and replaced with the identical mucosal and serosal solutions present during the $2^{\circ} \mathrm{C}$ incubation but their temperature was $23^{\circ} \mathrm{C}$. Osmotic water flow was measured gravimetrically. The values shown represent the mean \pm SEM of six independent experiments.

thelial osmotic water flow at $2^{\circ} \mathrm{C}$ did not attenuate, but remained remarkably stable (Fig. 8). Rewarming bladders to $23^{\circ} \mathrm{C}$ in the presence of the 175 mosM gradient resulted in an initial rate of osmotic water flow similar to the initial flow rate in Fig. 1 followed by rapid attenuation.

The rate of osmotic water flow observed at $2^{\circ} \mathrm{C}$ is $\sim 37 \%$ of the initial rate observed in other bladders at $23^{\circ} \mathrm{C}$. This decrease in water flow can be attributed solely to the effect of temperature on water flow. To demonstrate this, bladders were stimulated with $\mathrm{ADH}$ for $15 \mathrm{~min}$ in the absence of a gradient and then the mucosal surface was fixed with glutaraldehyde by the method of Eggena (19). Osmotic water flow was then repetitively measured in the same fixed hemibladder using 175 mosM gradients at $2^{\circ}$ and $23^{\circ} \mathrm{C}$. In these fixed bladders, osmotic water flow decreased to $42 \pm 8 \%(n=3)$ upon cooling to $2^{\circ} \mathrm{C}$ and returned to its original value upon rewarming. Similar data have been obtained by Kachadorian et al. (40).

Inclusion of fluorescent markers during the maneuvers used for the experiment in Fig. 8 revealed: (a) no granular cell uptake of F-dextran at $2^{\circ} \mathrm{C}$ even in the presence of a 175 mosM gradient (data not shown) and (b) upon rewarming, the pattern of Fdextran uptake indistinguishable from that observed in bladders stimulated with ADH in the absence of a gradient followed by exposure to a 175 mosM gradient (see Fig. 5 B).

Water permeability and fluorescent marker uptake of bladders stimulated with $A D H$ in the continuous presence of an osmotic gradient. The foregoing results were obtained in bladders stimulated with $\mathrm{ADH}$ for 15 min under isotonic conditions prior to exposure to an osmotic gradient. It is possible that the decrease in water permeability and uptake of fluorescent markers by 
granular cells do not occur in bladders which are initially stimulated in the continuous presence of an osmotic gradient. Under these conditions, water flow across the granular cell may regulate the insertion of water channels and thus alter the pattern of apical membrane retrieval. ADH stimulation of bladders in the presence of an osmotic gradient is the condition that occurs in situ and has been used in most toad bladder experiments in the literature. We therefore studied paired hemibladders which were stimulated in the continuous presence of an osmotic gradient.

Paired hemibladders were suspended in a $175^{\circ}$ mosM gradient at $23^{\circ} \mathrm{C}$ and stimulated with $50 \mathrm{mU} / \mathrm{ml}$ of ADH. In one hemibladder, osmotic water flow was measured every 2 min to determine the time of peak water flow (Fig. 9, top). At this point, the companion hemibladder was rapidly chilled to $2^{\circ} \mathrm{C}$ (Fig. 9, bottom). In the chilled hemibladder water flow rapidly decreased to $41 \%$ of the peak value and remained constant for an interval of $20 \mathrm{~min}$. Upon rewarming, the initial rate of water flow was $140 \%$ of the peak value measured prior to cooling. This was

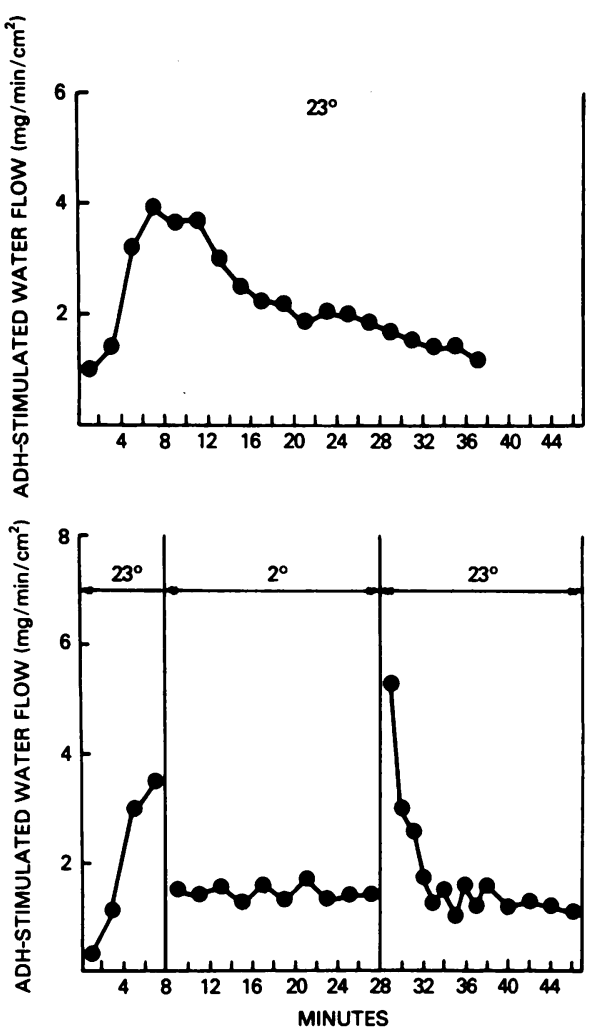

Figure 9. The effect of rapid cooling on paired hemibladders continuously exposed to a 175 mosM gradient. The control hemibladder sac (top) was filled with a hypotonic Ringer's solution $(40 \mathrm{mosmol} / \mathrm{kg}$ $\mathrm{H}_{2} \mathrm{O}$ ) and suspended in Ringer's solution containing $50 \mathrm{mU} / \mathrm{ml}$ of $\mathrm{ADH}$ at $23^{\circ} \mathrm{C}$. Osmotic water flow was measured gravimetrically. The experimental hemibladder sac (bottom) was stimulated with ADH under identical conditions until the interval of peak osmotic water flow was attained. At this point, both mucosal and serosal solutions were removed and replaced with ones identical to those previously present, but their temperature was chilled to $2^{\circ} \mathrm{C}$. The apparatus used to suspend the bladder was placed in an ice bath and osmotic water flow was measured every 2 min during this 20 -min incubation period. The mucosal and serosal solutions were then removed and replaced with solutions identical to those previously present, but their temperature was again $23^{\circ} \mathrm{C}$. Osmotic water flow was measured in 1 -min intervals. These tracings are representative of eight similar experiments.
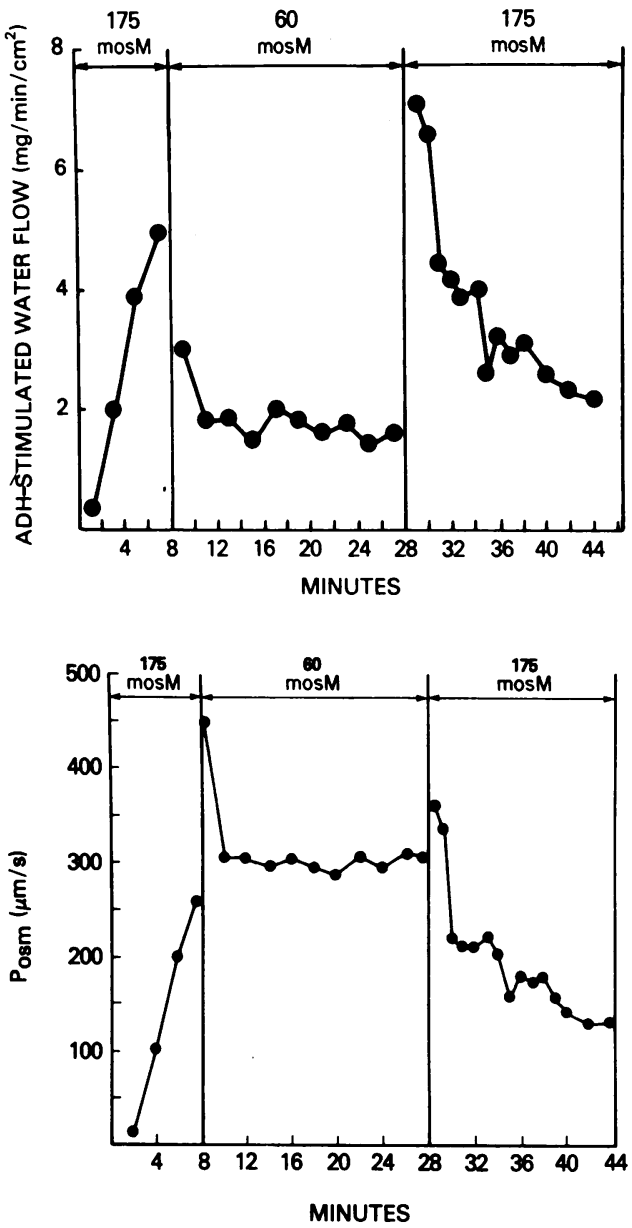

Figure 10. The effect of a period of low transepithelial water flow on paired hemibladders exposed to a $175 \operatorname{mosM}$ gradient at $23^{\circ} \mathrm{C}$. The control hemibladder sac (not shown) was treated as described in Fig. 9 and the interval to peak osmotic water flow was determined. The experimental hemibladder sac (top) was stimulated with ADH under identical conditions until the interval of peak water flow was obtained. At this point, the mucosal and serosal solutions were removed. These were replaced with a hypotonic mucosal solution (155 mosmol/kg $\mathrm{H}_{2} \mathrm{O}$ ) and an isotonic $\left(215 \mathrm{mosmol} / \mathrm{kg} \mathrm{H}_{2} \mathrm{O}\right.$ ) serosal solution containing $50 \mathrm{mU} / \mathrm{ml}$ of $\mathrm{ADH}$ at $23^{\circ} \mathrm{C}$. After a 20 -min incubation period, the two solutions were again removed and replaced with a hypotonic mucosal solution ( 40 mosmol/ $/ \mathrm{kg} \mathrm{H}_{2} \mathrm{O}$ ) and a serosal solution identical to that present during the previous incubation period. Osmotic water flow was measured gravimetrically. The changes in $P_{\text {osm }}$ that occur in the bladder depicted in the upper panel are displayed in the bottom panel. This tracing is representative of an experiment performed a total of five times.

followed by a rapid decrease in water flow which occurred within $\sim 5 \mathrm{~min}$. These results are not produced exclusively by exposure to cold. A similar pattern of changes in water permeability occurred when water flow was reduced by substitution of a 60 mosM gradient at $23^{\circ} \mathrm{C}$ for the 175 mosM gradient at $2^{\circ} \mathrm{C}$ (Fig. 10, top). Calculation of $P_{\text {osm }}$ under these conditions (Fig. 10, bottom) showed that $P_{\text {osm }}$ remained stable throughout the 20min period of incubation with the 60 mosM gradient. This was followed by a rapid decrease after institution of a 175 mosM gradient.

As previously shown in Fig. 5, there is uptake of F-dextran in the presence of a 175 mosM gradient after a $15-\mathrm{min}$ period 
of ADH stimulation in that gradient. There was little or no uptake of label in hemibladders during the intervals of cold (data not shown) or 60 mosM gradient exposure (Fig. 11, left). After these maneuvers, a large uptake of F-dextran or R-HRP occurred during the 16-min period when water flow rapidly attenuated (Fig. 11 right).

Thus, even when bladders are stimulated with $\mathrm{ADH}$ in the continuous presence of an osmotic gradient, osmotic water permeability is stabilized by conditions that arrest membrane retrieval. This occurs during a period of reduced transepithelial water flow resulting from either low temperature or a low osmotic gradient. A subsequent increase in temperature or applied osmotic gradient causes an initial period of increased water flow followed by its rapid attenuation with concomitant apical membrane retrieval. These observations indicate that membrane retrieval dependent on water flow represents a physiologically important mechanism that regulates the apical membrane water permeability response to $\mathrm{ADH}$.

\section{Discussion}

These experiments were performed to study flux inhibition of the water permeability response of ADH stimulated toad urinary bladder. The experiments described in Fig. 1-8 involved bladders stimulated with ADH in the absence of an osmotic gradient. These conditions are known to produce maximal $P_{\text {osm }}$ and particle aggregates and near-maximal aggrephore fusion events in the granular cell apical membrane $(20,21)$. Upon institution of a 175 mosM transepithelial gradient, there was a rapid attenuation of osmotic water flow to $\sim 25 \%$ of its original value. Similar results were reported by Parisi et al. (24) in frog urinary bladder. These authors also showed that the rapid attenuation of water flow occurred as well after stimulation with 8-bromocyclic AMP and that it did not occur after fixation of the mucosal surface with glutaraldehyde. Muller and Kachadorian (22) have recently shown that luminal membrane particle aggregates and aggrephore fusion events each decrease by $\sim 70 \%$ in toad bladders stimulated with ADH under isosmotic conditions for $1 \mathrm{~h}$, then exposed to a 175 mosM gradient for $1 \mathrm{~h}$. All these data support the concept that the decrease in tissue water permeability occurs at the granular cell apical plasma membrane which acts as a flow-limiting barrier.

We observed (Fig. 1) that if ADH-stimulated bladders are exposed to various transepithelial osmotic gradients, there is progressive diminution of water flow so that by 15 -min the osmotic water flows are similar regardless of the osmotic driving force. Under these conditions, the initial rate of water flow is proportional to the osmotic gradient, but this relationship is modified with time. Osmotic water permeability $\left(P_{\text {osm }}\right)$ shows a time-dependent decrease which is proportional to osmotic driving force such that there is an $80 \%$ decrease in $P_{\text {osm }}$ with a 220 mosM gradient.

Several of the findings reported here support the concept of a response "threshold" for membrane retrieval when the toad bladder is exposed to various osmotic gradients. In Figs. 1 and 3 , little change in the rate of osmotic water flow or $\boldsymbol{P}_{\text {osm }}$ occurs with 30 or 60 mosM gradients. There is minimal internalization of HRP upon exposure to a 60 mosM gradient as detected by fluorescence (Fig. 11, left) or enzymatic assay (Fig. 7). Furthermore, Fig. 10 (bottom) shows no decrease in $P_{\text {osm }}$ during the interval when the 60 mosM gradient is imposed. When ADH stimulated-toad bladders are exposed to gradients of $100 \mathrm{mosM}$ or greater, there is a nearly linear uptake of HRP (Fig. 7) and a decrease in $P_{\text {osm }}$ (Figs. 3 and 11, bottom).

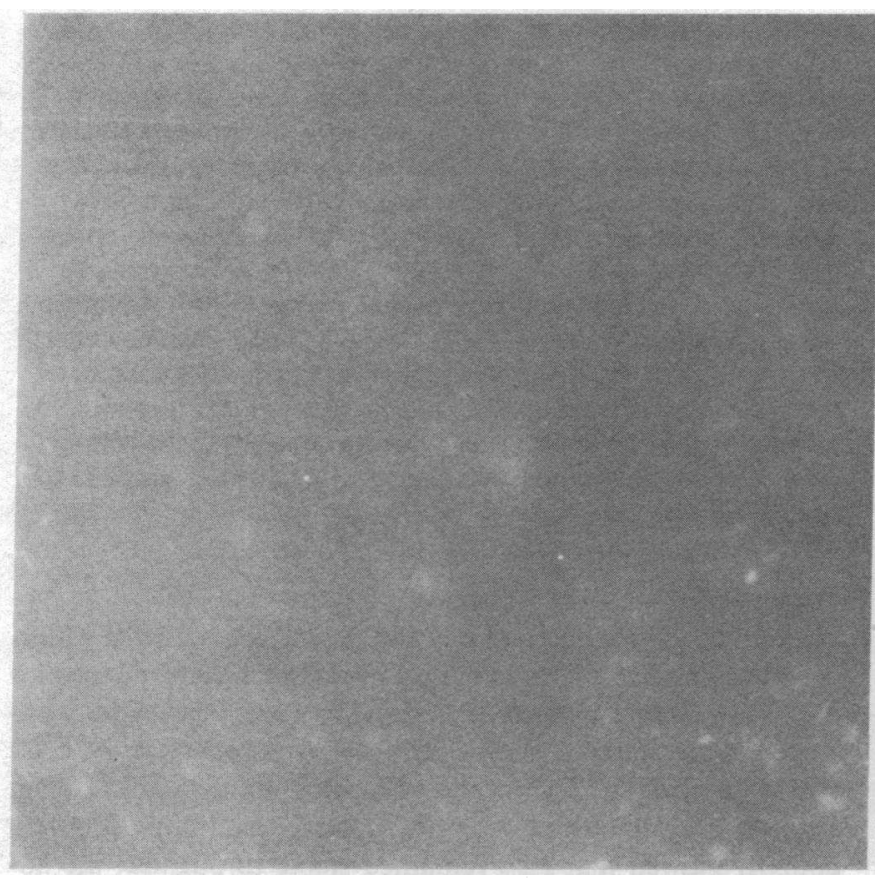

Figure 11. Granular cell uptake of R-HRP during periods of low osmotic water flow and subsequent exposure to a 175 mosM gradient. Toad bladder sacs were processed as detailed in Fig. 10. During the periods of exposure to either the 60 mosM gradient (left) or the subsequent period of 175 mosM gradient (right), R-HRP $(5 \mathrm{mg} / \mathrm{ml})$ was in-

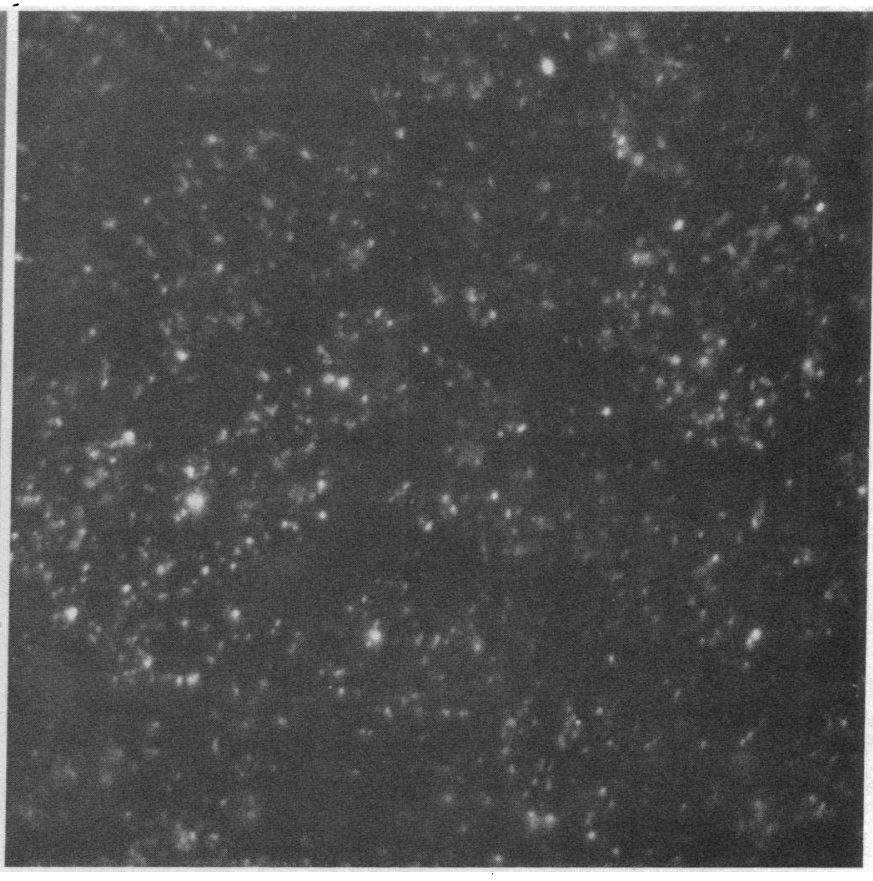

cluded in the mucosal solution. The mucosal solutions were then removed from the sacs, the mucosal surface was rinsed five times with the appropriate Ringer's solutions, and the bladder was mounted and observed by epifluorescence microscopy as detailed in Methods. $\times 4,232$. 
Aggrephores visualized by freeze-fracture electron microscopy are long tubular vesicles in the cytoplasm of granular cells and contain intramembrane particle aggregates (4). ADH stimulation induces the fusion of aggrephores with the granular cell apical plasma membrane inserting particle aggregates into its lipid bilayer. Fused aggrephores remain as deep invaginations on the apical membrane and do not appear to evaginate significantly (21). Removal of hormone results in the prompt disappearance of aggrephore fusions with the apical membrane as visualized by freeze-fracture electron microscopy (4). Under identical experimental conditions, inclusion of $\operatorname{HRP}(5,21)$ or ferritin (5) in the mucosal solution results in endocytosis of these markers into tubular vesicles that have the same size and shape as aggrephores seen in freeze-fracture preparations. The electron microscopic studies presented here show that the bulk of the HRP uptake is localized to long tubular vesicles. Furthermore, using the label fracture approach (41), we have recently obtained confirmation that these vesicles retrieve intramembrane particle aggregates along with colloidal gold or HRP from the mucosal bathing solution (42, unpublished observations).

Incubation of bladders at $2^{\circ} \mathrm{C}$ blocks the uptake of fluorescent markers despite the presence of large transepithelial osmotic gradients. Previous studies have shown that exposure to cold results in inhibition of aggrephore detachment and particle aggregate disappearance from the apical membrane without change in their morphological characteristics $(43,44)$. As shown in Figs. 8 and 9 , rewarming to $23^{\circ} \mathrm{C}$ causes an increase in water flow which is rapidly attenuated. There is concomitant stimulation of membrane retrieval. However, as shown in Figs. 10 and 11, inhibition of membrane retrieval is not produced solely by exposure to cold, but also occurs when transepithelial water flow is reduced to below an apparent threshold. Fig. 5 provides additional support for the concept that the extent of apical membrane retrieval is correlated with the magnitude of transepithelial water flow rather than exposure to a particular osmotic gradient. The uptake of fluorescent markers is increased (Fig. 5 B) during an interval when osmotic water flow is large (Fig. 1) as compared with conditions where water flow (Fig. 9, top) and marker uptake (Fig. $5 \mathrm{D}$ ) are diminished despite exposure to the same $175 \mathrm{mosM}$ gradient. Therefore, it seems likely that the major mechanism of flux inhibition is water-flow-dependent membrane retrieval. Because the retrieved membrane takes the form of long tubular vesicles containing intramembrane particle aggregates, we conclude that flow-dependent retrieval of intramembrane aggregates is responsible for flux inhibition. The present studies are not sufficient to establish a direct causal relationship between transepithelial water flow and apical membrane retrieval. Unfortunately, the information at hand does not support reasoned speculation.

There is disagreement as to the extent of membrane retrieval during ADH stimulation in the presence of a 175 mosM osmotic gradient. Analysis using freeze-fracture electron microscopy (4, $22,45)$ suggests that the bulk of the aggrephores remain fused and in continuity with the apical membrane as long as ADH is present. In contrast, inclusion of enzymatic $(25,26,46)$ or electron-dense (47) markers in a hypotonic mucosal solution results in labeled cytoplasmic tubular vesicles which do not appear to be connected to the apical surface (26). Our data do not support the concept that aggrephores remain fused with the apical membrane for the duration of exposure to $\mathrm{ADH}$ in the presence of a 175 mosM osmotic gradient. The data from Figs. 5, 7, and 11 show the uptake of dextran and HRP after ADH stimulation depends on the presence of an appropriate osmotic gradient/ water flow and confirms previous results of Masur et al. (25).

In summary, our results suggest that the apical plasma membrane of the ADH-stimulated granular cell is a dynamic structure particularly during the initial 30 -min period of stimulation. In the absence of net water flow, insertion of aggrephores occurs rapidly, $P_{\text {osm }}$ is markedly increased, and membrane retrieval is negligible. In the presence of net water flow which is greater than the threshold value, there is increasing membrane retrieval and decreasing $P_{\text {osm }}$ depending on the rate of water flow. The flow-dependent decrease in $P_{\text {osm }}$ has been termed flux inhibition. The uptake of markers into tubular vesicles during this period represents the retrieval of fused aggrephores. The number of fused aggrephores remains remarkably constant after 5 min of ADH stimulation in the presence of a 175 mosM gradient (21), despite the fact that continued retrieval of fused aggrephores occurs during the subsequent $25 \mathrm{~min}$. Under these conditions, the rapid rise and subsequent modulation of osmotic water flow is likely governed by the rates of fusion and retrieval of aggrephores. Changes in the transepithelial water flow during ADH stimulation alters the rate of membrane retrieval and thus apical membrane water permeability. Although other factors such as modification of apical water channel permeability by pH $(44,48)$, a distal or second permeability barrier $(35)$, or changes in the granular cell cytoskeletal organization (49) may have additional effects on ADH-elicited $P_{\text {osm }}$, aggrephore turnover within the apical membrane is a major factor governing water permeability in ADH-stimulated toad urinary bladder and accounts for flux inhibition.

\section{Acknowledgments}

The authors wish to thank Drs. Kenneth Spring and Kevin Strange for their helpful discussions. We are indebted to Dr. Pierre Henkart for the use of his fluorescence microscope and Kathy Lowe for technical assistance with the electron microscopy.

H. William Harris Jr. was supported by Clinician-Scientist Award 84-428 from The American Heart Association (AHA) and with funds contributed in part by AHA-Massachusetts Affiliate. James B. Wade was supported by grant AM-32839 from the National Institutes of Health.

\section{References}

1. Handler, J. S., and J. Orloff. 1973. The mechanism of action of antidiuretic hormone. Handb. Physiol. (Renal Physiol. Sect. 8) 791-814.

2. Orloff, J., and J. S. Handler. 1967. The role of adenosine 3'5'cyclic monophosphate in the action of antidiuretic hormone. Am. J. Med. 42:757-768.

3. Humbert, F. R., A. Montesano, A. Grosso, R. C. DeSousa, and L. Orci. 1977. Paticle aggregates in plasma and intracellular membranes of toad bladder (granular cell). Experientia (Basel). 33:1364-1367.

4. Muller, J., W. A. Kachadorian, and V. A. DiScala. 1980. Evidence that ADH-stimulated intramembrane particle aggregates are transferred from cytoplasmic to luminal membranes in toad bladder epithelial cells. J. Cell Biol. 85:83-95.

5. Wade, J. B., D. L. Stetson, and S. A. Lewis. 1981. ADH action: evidence for a membrane shuttle hypothesis. Ann. N.Y. Acad. Sci. 372: 106-117.

6. Kachadorian, W. A., J. B. Wade, and V. A. DiScala. 1975. Vasopressin: induced structural change in toad bladder luminal membrane. Science (Wash. DC). 205:910-913.

7. Bourguet, J., J. Chevalier, and J. S. Hugon. 1976. Alterations in membrane-associated particle distribution during antidiuretic challenge in frog urinary bladder epithelium. Biophys. J. 16:627-639. 
8. Wade, J. B. 1985. Membrane structural studies of the action of vasopressin. Fed. Proc. 44:2687-2692.

9. Levine, S. D., M. Jacoby, and A. Finkelstein. 1984. The water permeability of toad bladder. II. The value of $P_{\mathrm{f}} / P_{\mathrm{d}(\mathrm{w})}$ for the antidiuretic hormone-induced water permeation pathway. J. Gen. Physiol. 83:543561.

10. Harmanci, M. C., W. A. Kachadorian, H. Valtin, and V. A. DiScala. 1978. Antidiuretic hormone-induced intramembranous alterations in mammalian collecting ducts. Am. J. Physiol. 235:F440-F443.

11. Harmanci, M. C., P. Stern, W. A. Kachadorian, H. Valtin, and V. A. DiScala. 1980. Vasopressin and collecting duct intramembranous particle clusters: a dose-response relationship. Am. J. Physiol. 239:F560 F564.

12. Brown, D., G. I. Shields, H. Valtin, J. F. Morris, and L. Orci. 1985. Lack of intramembranous particle aggregates in collecting ducts of mice with nephrogenic diabetes insipidus. Am. J. Physiol. 249:F582F589.

13. Edelman, I. S., M. J. Peterson, and P. F. Gulyassy. 1964. Kinetic analysis of the antidiuretic action of vasopressin and adenosine $3^{\prime} 5$ monophosphate. J. Clin. Invest. 43:2185-2194.

14. Schwartz, I. L., and R. Walter. 1967. Factors influencing the reactivity of the toad bladder to the hydro-osmotic action of vasopressin. Am. J. Med. 42:769-776.

15. Parisi, M., J. Bourguet, P. Ripoche, and J. Chevalier. 1979. Simultaneous minute by minute determination of unidirectional and net water fluxes in frog urinary bladder. A reexamination of the two barriers in series hypothesis. Biochim. Biophys. Acta. 556:509-523.

16. Hays, R. M., and A. Leaf. 1962. Studies on the movement of water through the isolated toad bladder and its modification by vasopressin. J. Gen. Physiol. 45:905-919.

17. Eggena, P. 1972. Glutaraldhyde-fixation method for determining the permeability to water of the toad urinary bladder. Endocrinology. 91:240-246.

18. Eggena, P., R. Walter, and I. L. Schwartz. 1968. Relationship between hydroosmotic flow and the inhibited response of the toad bladder to vasopressin. Life Sci. 7:59-63.

19. Eggena, P. 1972. Osmotic regulation of toad bladder responsiveness to neurohypophyseal hormones. J. Gen. Physiol. 60:665-678.

20. Ellis, S. J., W. A. Kachadorian, and V. A. DiScala. 1980. Effect of an osmotic gradient on ADH-induced intramembraneous particle aggregates in toad bladder. J. Membr. Biol. 52:181-184.

21. Muller, J., and W. A. Kachadorian. 1984. Aggregate-carrying membranes during ADH stimulation and washout in toad bladder. Am. J. Physiol. 247:C90-C98.

22. Muller, J., and W. A. Kachadorian. 1985. Regulation of luminal membrane water permeability by water flow in toad urinary bladder. Biol. Cell. In press.

23. Muller, J., and W. A. Kachadorian. 1983. Regulation of luminal membrane structure by osmotic water flow during $\mathrm{ADH}$ stimulation and washout in toad bladder. Kidney Int. 23:263. (Abstr.)

24. Parisi, M., P. Ripoche, G. Prevost, and J. Bourguet. 1981. Regulation by ADH and cellular osmolarity of water permeability in frog urinary bladder: a time course study. Ann. N.Y. Acad. Sci. 372:144-162.

25. Masur, S. K., S. Cooper, and M. S. Rubin. 1984. Effect of an osmotic gradient on antidiuretic hormone-induced endocytosis and hydroosmosis in the toad urinary bladder. Am. J. Physiol. 247:F370-F379.

26. Gronowicz, G., S. K. Masur, and E. Holtzman. 1980. Quantitative analysis of exocytosis and endocytosis in the hydroosmotic response of toad bladder. J. Membr. Biol. 52:221-235.

27. Harris, H. W. Jr., J. B. Wade, and J. S. Handler. 1986. Fluorescent markers to study membrane retrieval in ADH treated toad urinary bladder. Am. J. Physiol. (Cell Physiol.) In press.

28. Handler, J. S., R. Besinger, and J. Orloff. 1968. Effect of adrenergic agents on toad bladder response to ADH, 3'5'-AMP and theophylline. Am. J. Physiol. 215:1024-1031.

29. Bentley, P. J. 1958. The effects of neurohypophyseal extracts on water transfer across the wall of the isolated urinary bladder of the toad Bufo marinus. Endocrinology. 17:201-219.

30. Kachadorian, W. A., and S. D. Levine. 1982. Effect of distension on ADH-induced osmotic water flow in toad urinary bladder. J. Membr. Biol. 64:181-186.

31. Steinman, R. M., and Z. A. Cohn. 1972. The interaction of soluble horseradish peroxidase with mouse peritoneal macrophages in vitro. $J$. Cell Biol. 55:186-204.

32. Bradford, M. M. 1976. A rapid and sensitive method for quantitation of microgram quantities of protein utilizing the principle of protein-dye binding. Anal. Biochem. 72:248-254.

33. Graham, R. C., and M. J. Karnovsky. 1966. The early stages of absorption of injected horseradish peroxidase in the proximal tubule of mouse kidney: ultrastructural cytochemistry by a new technique. J. Histochem. Cytochem. 14:209-302.

34. Levine, S. D., and W. A. Kachadorian. 1981. Barriers to water flow in vasopressin-treated toad urinary bladder. J. Membr. Biol. 61: 135-139.

35. Kachadorian, W. A., S. Sariban-Sohraby, and K. R. Spring. 1985 Regulation of water permeability in toad urinary bladder at two barriers. Am. J. Physiol. 248:F260-F265.

36. Dainty, J. 1963. Water relations in plant cells. Adv. Botan. Res. 1:279-326.

37. Diamond, J. 1979. Osmotic water flow in leaky epithelia. $J$. Membr. Biol. 51:195-216.

38. Wright, E. M., A. P. Smulders, and J. M. Tormey. 1972. The role of the lateral intracellular spaces and solute polarization effects in the passive flow of water across the rabbit gallbladder. J. Membr. Biol. 7:198-219.

39. Silverstein, S. C., R. M. Steinman, and Z. A. Cohn. 1977. Endocytosis. Annu. Rev. Biochem. 46:669-722.

40. Kachadorian, W. A., J. Muller, S. W. Rudich, and V. A. DiScala. 1979. Temperature dependence of ADH-induced water flow and intramembranous particle aggregates in toad bladder. Science (Wash. DC). 205:910-913

41. Pinto de Silva, P., and F. W. Kan. 1984. Label-fracture: a method for high resolution labeling of cell surfaces. J. Cell Biol. 99:1156-1161.

42. Harris, H. W. Jr., R. A. Coleman, J. B. Wade, and J. S. Handler 1986. Water flow regulates apical membrane retrieval in antidiuretic hormone stimulated toad urinary bladder. Clin. Res. (Abstr.) In press.

43. Kachadorian, W. A., J. Muller, S. Rudich, and V. A. DiScala. 1981. Relation of ADH effects to altered membrane fluidity in toad urinary bladder. Am. J. Physiol. 240:F63-F69.

44. Parisi, M., R. Mortoreano, J. Chevalier, and J. Bourguet. 1981. Cellular $\mathrm{pH}$ and water permeability control in frog urinary bladder: a possible action on water pathway. Biochim. Biophys. Acta. 648:267274.

45. Kachadorian, W. A., S. Ellis, and J. Muller. 1979. Possible roles for microtubules and microfilaments in $\mathrm{ADH}$ action on toad urinary bladder. Am. J. Physiol. 236:F14-F20.

46. Masur, S. K., E. Holtzman, and R. Walter. 1972. Hormonestimulated exocytosis in the toad urinary bladder. J. Cell Biol. 52:211219.

47. Guohua, D., N. Franki, and R. M. Hays. 1985. Evidence for cycling of aggregate containing tubules in toad urinary bladder. Clin. Res. 33:618. (Abstr.)

48. Parisi, M., and J. Bourguet. 1984. Effects of cellular acidification on ADH-induced intramembrane particle aggregates. Am. J. Physiol. 246:C157-C159.

49. Dibona, D. R. 1983. Cytoplasmic involvement in ADH-mediated osmosis across toad urinary bladder. Am. J. Physiol. 245:C297-307. 